\title{
Acknowledgments
}

In translating and editing This Is Not a Pipe, I had the assistance of a number of persons I should like to thank here.

First and most important was Dr. Sarah Lawall, Professor of Comparative Literature at the University of Massachusetts, who guided my early study of Michel Foucault. She read each draft of the translation and gave inestimable help on the way to a completed manuscript. Dr. Lawall's wide knowledge and impeccable scholarship prevented several allusions from escaping unnoticed and greatly improved the overall quality of the translation. Her colleague, Dr. Roger Green of the French Department at the State University of New York at Albany, helped unravel a couple of the more complicated puns.

I am grateful to M. Bruno Roy, at Éditions fata morgana, for aiding in securing translation rights to the text of Michel Foucault's Ceci n'est pas une pipe (Montpellier: Éditions fata morgana, 1973). Mr. Harry Torczyner, representative of René Magritte's estate and attorney for A.D.A.G.P., helped me acquire permission to reproduce the paintings that illus- 
trate the present volume, none of which were included in the French version. Mr. Torczyner also provided photographs of two Magritte canvases in his private collection.

I particularly appreciate the efforts of the following individuals for photographs of paintings: $\mathrm{Mr}$. and Mrs. Nesuhi Ertegun; Mr. Eric Himmel, of Abrams Publishing Company; Ms. Hildagard Kron; Mme. René Magritte; Dr. Karin Frank v. Maur, of Staatsgalerie Stuttgart; Mme. Annette Minét, of Draeger, Maître Imprimeur; Mr. Richard Oldenburg and the research library staff of the Museum of Modern Art; M. Louis Scutenaire; and Mr. David Sylvester, of the Menil Foundation's René Magritte Catalogue Raisonné project.

Finally: to Dr. and Mrs. Clifton R. Wharton, Jr., my thanks for access to library and catalog resources, and for red-tape cutting par excellence. To Mr. William McClung of the University of California Press and my editor Ms. Marilyn Schwartz, my gratitude for able guidance and-above all-patience. 


\section{THIS IS NOT A PIPE}


